\title{
In Memory of Professor Terence ('Terry') Hawkes
}

\author{
John Drakakis
}

In the preface to his collection of essays That Shakespeherian Rag (1986) the author reported that 'an early impulse to call the book Eminent Shakespearians was quietly and efficiently throttled, and I am grateful to its assassins'. Terence Hawkes, who died at the age of 82 on 16 January 2014, could comment wittily on the genesis of a collection of innovative essays that brought together his own unique and distinctive approach to Shakespeare studies with a lifelong love of jazz and poetry. The title was from T.S. Eliot's 'The Waste Land' and was an oblique reference to Hawkes' own formative hobby as a highly proficient jazz drummer.

Terence Hawkes, a proud native of Birmingham, spent much of his professional career in the principality at what was University College Cardiff, later to become the University of Cardiff, which by 1986 had become the centre of a distinctive brand of literary and cultural theory. Well before the emergence of North American notions of Renaissance self-fashioning he was more self-conscious than most of his contemporaries, which meant that in addition to literature being a 'production', the academic persona was also a fabrication. His carefully choreographed lectures to packed student audiences in the 1960s and later were supported by scholarly publications, beginning in 1959 with an edited selection of Coleridge's writings on Shakespeare, followed by the monograph Shakespeare and The Reason in 1963. Hawkes was one of the first of a generation of Shakespeare scholars to make the connection between 'Shakespeare' and 'popular culture', following in the footsteps of S.L. Bethel, to whose Shakespeare and The Popular Tradition he had been exposed as an undergraduate and a postgraduate at Cardiff in the 1950s. His second book was the innovative Shakespeare's Talking Animals (1973), which was well in advance of its time, and which sought to link Shakespeare's theatre with the 'global village' that the Canadian 
cultural commentator Marshal McLuhan identified as an important feature of the rapidly burgeoning modern media. Already at this stage, Hawkes was beginning to feel the pressure of what was to be an explosion in the development of literary theory in the late 1970s.

Here again, he was at the forefront, and masterminded the New Accents series to which he contributed one of the first four inaugural volumes Structuralism and Semiotics (1977). This series, in which he recruited scholars in literary, cultural and media studies, was to prove seminal in changing the direction of the humanities generally within the academy and beyond. Volumes such as Deconstruction: Theory and Practice, Re-reading English, Sub-culture: The Meaning of Style, Reading Television, Critical Practice, Translation Studies, Formalism and Marxism, Sexual/Textual Politics, Alternative Shakespeares, and Post-colonial Shakespeares, to name but a few that appeared over the succeeding 20 years - many of which have gone through second and third editions and have all made a major contribution to the shaping of the critical sensibilities of generations of students. The hallmark of the series, and what conservative detractors saw as its danger, was the presentation of complex literary, cultural and philosophical ideas in clear, accessible analytical prose, and Hawkes brought his formidable editorial skills to bear on ensuring its ethos. Indeed, by the mid 1980s there were few major world conferences on Shakespeare that did not have as part of their programme a plenary lecture by Terence Hawkes.

Hawkes' lecturing style was unique; he always began by addressing his audience as 'ladies and gentlemen', which was followed by a reference to some contemporary popular event of the day. As a close reader of the nuances of linguistic idiom, evidenced by his European editorship for some time of the journal Language and Style, he was aware, long before Foucault's essay on 'The Order of Discourse', of what it meant to engage an audience in public discourse; one of his favourite gambits was 'before I speak I would like to say something'. His lectures were characterised by an exquisite sense of dramatic timing, frequently comic, and always exposing the pretensions, inconsistencies and contradictions inherent in the material he was dealing with. He was deeply suspicious of the claims made by the theatrical establishment that performances were 'live', and he developed this thesis in a series of talks for radio that were published in The Listener in the late 1960s. His claim was one that the late Raymond Williams went on to elaborate, that 'theatre' and 'drama' 
were not synonymous, and that the venue for serious 'drama' had migrated to what was then the relatively new medium of television.

This exquisite sense of timing - a transfer of training that, regrettably, no longer features as part of the justification for higher education - was derived from Hawkes' formative experience as a jazz drummer, playing behind impresarios such as Acker Bilk, Digby Fairweather, and on one occasion the legendary jazz trumpeter Wild Bill Davison when he performed in Cardiff. Indeed, when asked in a radio programme shortly after his retirement from university teaching what his abiding memory was, he pointed mischievously, and without hesitation, to his backing of Wild Bill Davison. All of Hawkes' work, whether in print or in the lecture room, is characterised by a firm, regular rhythm, which gives it a structure and which permits occasional improvisations and deviations, while at the same time providing a firm melodic line. It also discloses a delight in dialogue, and, whether in the pub, on the bandstand, in the lecture room, or in print, his interlocutors were cajoled, seduced, persuaded, and at times incited, to respond.

Terence Hawkes was also a keen football supporter, and he and his wife Ann, to whom all of his books are dedicated, were familiar figures on the terraces at Cardiff City Football Club. That to some of his friends he always seemed like a declaration of cheery optimism has more recently proved to have been justified. That persistent optimism was put to good use in a series of British Council Summer Schools that he masterminded in Salamanca, Varenna, Solothurn, and in Tours, and that attracted students from across the world. For the first Salamanca Summer School he chose as lecturers what he called his 'first eleven', almost all of whom went on to occupy university chairs. All of these events produced distinctive and often hilarious memories, but none more controversial was the now legendary confrontation between the late Antony Easthope and the novelist Malcolm Bradbury at Solothurn, which taxed Hawkes' formidable powers of wit and diplomacy to the limit. On this occasion, and on others, he was accompanied by his wife Ann, who, behind the scenes, was frequently called upon to exercise her own considerable diplomatic skills in soothing bruised egos and arbitrating between incensed and mutually hostile middle-European fanaticisms. It was no mere domestic courtesy that each of Hawkes' books is dedicated to 'Ann'. In addition to pursuing her own life as a magistrate and judge maintaining law and order in South Wales, Ann was a constant 
support throughout, but particularly during the last two years of his life as he battled against cancer. After a serious stroke some years ago that deprived him of the power of speech, it was Ann who revived Terry's cognitive faculties by insisting that he assemble jigsaw puzzles, and that he drink (what was anathema to him as a beer drinker) a glass of red wine a day.

During the 1990s Hawkes produced a succession of books that sought to refine what had become a distinctive critical process. Beginning with Meaning By Shakespeare (1992), and culminating in Shakespeare in The Present (2002), he pioneered a distinctive brand of literary presentism that involved an intricate account of the scholarly enquirer's self-conscious, or at times unconscious, investment in the past. Much of this work has filtered through into another very successful series, New Accents on Shakespeare, which he continued to edit up until his death. Included in this series is a collection of essays entitled Presentist Shakespeares that he co-edited with the North American Shakespeare scholar Hugh Grady, and his last publication was an essay on 'Macbeth in The Present' that he contributed to a volume in the Arden Early Modern Drama Series, Macbeth: A Critical Reader.

Terence Hawkes was a unique and distinctive presence in both the field of Shakespeare studies and critical theory. He was the founding editor of the journal Textual Practice, and as an editor he was indefatigable in encouraging young scholars, in imparting good advice, and in giving generously of his time and his expertise. His own writing is characterised by an enthusiasm that is close to Brecht's notion of spass, a performative exuberance that inspires and stimulates critical engagement, and it stands as a rebuke to the new brand of dull managerialist (often pseudo-scholarly) professionalism. Hawkes always took seriously his position at the University of Wales, which was set up from donations made by Welsh miners, and his political position on the 'margins' has progressively made him symbolically central not just to Shakespeare studies but to literary and cultural studies more generally. It is significant that although he looked to the past and to Shakespeare, he never overlooked the present, never ceased to interrogate his own 'process', and he has left us with a critical blueprint for the future that is at the forefront of the humanities. His distinctive voice, his wit and his intellectual energy will continue to resonate with scholars in the humanities, as both an encouragement and a challenge - a stimulus to thought that is the bequest of an original mind. 